\title{
"For the Reputation and Respectability of the State": Trade, the Imperial State, Unfree Labor, and Empire in the Dutch Atlantic
}

\author{
Pepijn Brandon and Karwan Fatah-Black
}

Introduction

In a controversial but influential article published in 1999, the Dutch historians Piet Emmer and Wim Klooster characterized the early modern Dutch Atlantic as an example of expansion without empire. ${ }^{1}$ While Wim Klooster in the meantime seems to have tacitly moved away from this notion, Piet Emmer has repeatedly reaffirmed it. ${ }^{2}$ The central idea behind his thesis is that the Dutch provided a unique model of "purely mercantile expansion" that in fundamental ways "differed from a policy designed by a central state in shaping the foundations of a maritime empire."3

Piet Emmer's insistence on the non-imperial form of expansion rests at least in part on an anachronism. When held against the nineteenth century British ideal type, it could indeed be argued that the Dutch did not have a similar system in which they combined direct and indirect rule to control the sum of their Atlantic domains. The initial plans for the Dutch Atlantic, known as the Groot Desseyn (Grand Design), did envision a centrally ruled empire. ${ }^{4}$

1 P.C. Emmer and W.W. Klooster, "The Dutch Atlantic, 1600-180o: Expansion Without Empire," Itinerario vol. 23, no. 2 (1999): 48-69. For the influence of this thesis on Dutch Atlantic studies, see Gert Oostindie and Jessica Vance Roitman, "Repositioning the Dutch in the Atlantic, 1680-180o," Itinerario vol. 36, no. 2 (2012): 129-16o.

2 While still stressing the differences with "princely" states and their expansion, Wim Klooster's more recent contributions explicitly address the question of power-projection in the Netherlandic world. E.g. Wim Klooster, "The Place of New Netherland in the West India Company's Grand Scheme," in Joyce D. Goodfriend ed., Revisiting New Netherland. Perspectives on Early Dutch America (Leiden/Boston: Brill, 2005), 57-70, and Wayne te Brake and Wim Klooster, "Introduction," in Wayne te Brake and Wim Klooster eds., Power and the City in the Netherlandic World (Leiden/Boston: Brill, 2006), 1-11.

3 Pieter C. Emmer, "The Dutch and the Atlantic Challenge, 1600-180o," in P.C. Emmer, O. PétréGrenouilleau and J.V. Roitman eds., A deus ex Machine Revisited: Atlantic Colonial Trade and European Economic Development (Leiden/Boston: Brill, 2006), 151-177, 164.

4 Henk den Heijer, De geschiedenis van de wIC (Zutphen: Walburg Pers, 2002), 69-73.

(C) KONINKLIJKE BRILL NV, LEIDEN, 2016 | DOI 10.1163/9789004285200_006

This is an open access chapter distributed under the terms of the Creative Commons Attribution-

Noncommercial 3.0 Unported (CC-BY-NC 3.0) License. 
The Design rested on the idea that Brazil could become the seat of colonial rule, similar to Batavia on Java, or the Portuguese example of Goa in Asia. In practice, however, the Dutch Atlantic saw a more fragmented governing system in which Dutch cities and provinces had special interests in particular colonies, and the West India Company, formally chartered in 1621 with the monopoly of all trade in the Atlantic basin, farmed out its responsibilities in so-called patroonships or through subsidiary chartered companies. Already in 1630 and especially from 1640 onward the wIC lost many of its privileges to private traders. This continued throughout the seventeenth century until it also lost its exclusive rights to the Dutch slave trade in the 1730s. Private enterprise outside the wIC made up about 70 per cent of the Atlantic trade and shipping of the Dutch. ${ }^{5}$ In contrast to its East-Indian counterpart, the voc, the Dutch West India Company only took a small share of the total Dutch Atlantic activities.

However, the lack of formal unity, the prevalence of private enterprise and the absence of a clear command center in the Dutch Atlantic for much of the early modern period does not mean that state power and territorial control were insignificant factors in Dutch Atlantic expansion. Likewise, the question of labor requirement that was central to the economic structure of the Dutch Atlantic was at key points solved through state and state-like institutions. Regarding labor, the Dutch were at a particular disadvantage compared to the French, English and Iberians since their sources of manpower were limited within the Republic. ${ }^{6}$ This increased the need for the Dutch to rely on a multiplicity of supply lines, and on a wide range of negotiated labor relations. On occasion this meant that they were luring workers to their Atlantic domains offering good terms and conditions, but in others, brutal force was the only way they could alleviate their permanent labor shortages. Territoriality crucially determined the ways this force was meted out, whether it was by creating the operating bases for the slave-trade on the West-African coast and in the Caribbean, by setting the geographic perimeters of the Dutch slave production system, or by creating the physical boundaries between bondage and escape.

This article aims to show in what ways, directly or through subsidiary institutions, state intervention remained central to the functioning of the Dutch in the Atlantic. In doing so, it provides an alternative to trade-centered accounts of Dutch Atlantic expansion, in which the state and warfare have virtually been written out of the story. Both during the initial forceful entry of the Dutch

5 Henk den Heijer and Victor Enthoven, "Nederland en de Atlantische wereld, 1600-1800. Een historiografisch overzicht," Tijdschrift voor Zeegeschiedenis vol. 24, no. 2 (2005): 147-166.

6 Gijs Kruijtzer, "European Migration in the Dutch Sphere," in Gert Oostindie ed., Dutch Colonialism, Migration and Cultural Heritage (Leiden: KITLV Press, 2008), 97-154. 
in the Atlantic, as well as in later stages when the protection of its trading connections became the mainstay of its activity, the defense of small albeit crucial territories remained a priority to the state, the directors of Dutch colonial companies, as well as private merchants.

\section{The Brokerage Form of Dutch Commercial Expansion}

One of the causes for the notion of a Dutch Atlantic void of power-play-at least after the first steps towards large scale territorial expansion in Brazil came to nothing - is the seemingly subordinate role of the state beyond European waters. Both warfare and administration in the West and the East were "outsourced" to the main merchant enterprises. However, both the typical form of organization of these companies and the commercio-political networks of their directors in practice tied them firmly to the state.

For the Dutch, their empire was not only pristinely commercial in its aims, but also in its forms of organization. ${ }^{7}$ As Niels Steensgaard emphasized long ago, the Dutch merchant companies turned around the relationship between profit and power that underlay their Portuguese predecessor. Rather than acting as tributary enterprises to provide revenue to the state, the VOC and WIC incorporated a substantial part of their "protection costs" into their trade balance, making warfare a direct subsidiary to the accumulation of capital by their merchant-investors. ${ }^{8}$ This model was well suited for a state that excelled in what Charles Tilly dubbed "brokerage"; the outsourcing, wholesale or in part, of warring tasks to independent or semi-independent entrepreneurs who executed these tasks with the aim of making a profit. ${ }^{9}$

7 Hugo Grotius already theorized this marked difference between the Dutch empire and earlier forms of imperial expansion. Martine Julia van Ittersum, "The Long Goodbye: Hugo Grotius' Justification of Dutch Expansion Overseas, 1615-1645," History of European Ideas vol. 36 (2010): 386-411. For a wider intellectual context, see Arthur Weststeijn, "Republican Empire. Colonialism, Commerce and Corruption in the Dutch Golden Age," Renaissance Studies, vol. 26, no. 4 (2012): 491-509.

8 Niels Steensgaard, Carracks, Caravans and Companies. The Structural Crisis in the EuropeanAsian Trade in the Early 17th Century (Copenhagen: Lund, 1973), 114, and Giovanni Arrighi, The Long Twentieth Century: Money, Power, and the Origins of Our Times (London/New York: Verso $2002[1994]), 127 \mathrm{ff}$.

9 Charles Tilly, Coercion, Capital, and European States, AD 990-1992 (Cambridge, MA/Oxford: Blackwell, 1992), 29. For the brokerage character of the early modern Dutch state, see Pepijn Brandon, Masters of War: State, Capital, and Military Enterprise in the Dutch Cycle of Accumulation, 1600-1795 (Leiden/Boston: Brill, 2014), especially Chapters 1 and 2. 
The 35th condition of the voc charter, drawn up by the States General in 1602, famously granted the company the right beyond Cape Hope and the Straits of Magellan "to make alliances as well as contracts with princes and potentates in the name of the States General of the United Netherlands, (...) to build fortresses and strongholds there, summon and employ governors, soldiers, and public prosecutors (...)." ${ }^{10}$ The 1621 wIC charter mirrored this clause for the Atlantic to the letter, with the significant difference that the conditions on war and diplomacy came much earlier in the text, reflecting the even more warlike ambitions that drove the decision to erect a chartered company for the West Indies. ${ }^{11}$ Coming right after the end of the twelve years' truce between the Dutch Republic and the Habsburg Empire, the WIC was seen primarily as a tool to make deep incursions into the core overseas possessions of the Spanish crown, and this was also reflected in the charter by the adding of extra clauses that were absent from the VOC charter promising the WIC state support in the form of soldiers and fortresses. ${ }^{12}$

The inclusion of promises of state support into the very constitution of the WIC already signifies that this early form of "privatized" warfare did in no way lead to a passive role of the state towards global commercial ventures. Neither were these promises simply empty phrases. Especially in the early decades when both the independent existence of the state and the position of the voc and WIC overseas were continuously threatened by war with the Habsburg Empire, the commercial companies and the state always assisted each other with military and financial aid in times of need..$^{13}$ The organizational structure

10 "Octroy, by de Hoogh Mog. Heeren Staten Generael der Vereenighde Nederlanden verleendt aen de Oost-Indische Compagnie," Recueil van alle de placaten, ordonnantien, resolutien, instructien, lysten en waarschouwingen, betreffende de Admiraliteyten, convoyen, licenten en verdere zee-saeken. Volume II (The Hague: Paulus Scheltus, 1701), 12-13.

11 Den Heijer, Geschiedenis van de wIC, 33-34.

12 Conditions II-VII of the charter. Octroy, by de Hooghe Mogende heeren Staten Generael verleent aende West Indische Compagnie, in date den derden Junij 1621. Mette Ampliatien van dien, etc. (The Hague: Wede en erfgenamen Van Wouw, 1637).

13 For the voc, see Victor Enthoven, "Van steunpilaar tot blok aan het been. De Verenigde Oost-Indische Compagnie en de Unie," in Gerrit Knaap and Ger Teitler eds., De Verenigde Oost-Indische Compagnie tussen oorlog en diplomatie (Leiden: KITLV Uitgeverij: 2002), 35-58, Idem, "Mars en Mercurius bijeen. De smalle marges van het Nederlandse maritieme veiligheidsbeleid rond 1650," in Leo Akveld et al. eds., In het kielzog. Maritiemhistorische studies aangeboden aan Jaap R. Bruijn bij zijn vertrek als hoogleraar zeegeschiedenis aan de Universiteit Leiden (Amsterdam: De Bataafse Leeuw, 2003), 40-60, and Alfred Staarman, "De voc en de Staten-Generaal in de Engelse Oorlogen: een ongemakkelijk bondgenootschap," Tijdschrift voor Zeegeschiedenis vol. 15, no. 1(1996): 3-24. For the wIC, see Den Heijer, Geschiedenis van de wIC, 39-41. 
of the VOC and WIC guaranteed that lines of communication with the relevant bureaucratic bodies always remained short. This was true in particular for the relations between the colonial companies and the Admiralty Boards. Dutch naval administration, like the state in general, was organized federally, with five independent Admiralty Boards residing in different cities. The delegates on the boards were appointed for limited terms only by the different sovereign provinces, and within the provinces by the city councils of the leading towns and the nobility for the main rural areas. This created a complex form of crossrepresentation, that allowed especially the dominant merchant families of the Dutch Republic a tight grip on the commercially important naval affairs. ${ }^{14}$ While this federal structure of the navy is sometimes presented as a barrier to successful power projection at sea, Jan Glete has convincingly argued that especially in the seventeenth century, federalism allowed for forms of "interest aggregation" behind naval policy that made the Dutch state more rather than less efficient than most of its competitors. ${ }^{15}$

The organizational structure of the colonial companies resembled that of the federal Navy Boards so closely, that some have described the VOC as "an admiralty for Asia."16 Both the voc and the wIC were divided in chambers (six and five respectively) residing in leading commercial towns, often admiralty towns. The directors of these chambers were selected from the company investors, but often also fulfilled leading positions in the Dutch state at the local, provincial or "national" level. ${ }^{17}$ Later "patroonships" in Berbice and New Netherland, as well as chartered companies for Suriname and Essequibo

14 Pepijn Brandon, "Global Power, Local Connections: The Dutch Admiralties and Their Supply Networks," in Richard Harding and Sergio Solbes Ferri eds., The Contractor State and Its Implications, 1659-1815 (Las Palmas de Gran Canaria: Universidad de Las Palmas de Gran Canaria, Servicio de Publicaciones, 2012), 57-80.

15 Jan Glete, Navies and Nations. Warships, Navies and State Building in Europe and America, 1500-1860. Volume I (Stockholm: Almqvist \& Wiksell International, 1993), 154.

16 Oscar Gelderblom, Abe de Jong, and Joost Jonker, "An Admiralty for Asia. Isaac le Maire and Conflicting Conceptions about the Corporate Governance of the voc," Working Paper Erasmus Research Institute of Management, 2010.

17 As in almost every area, the political connections of voc directors have been investigated more thoroughly than those of their West Indian counterparts. E.g. Femme Gaastra, Bewind en beleid bij de voc: de financiële en commerciële politiek van de bewindhebbers, 1672-1702 (Zutphen: Walburg Pers, 1989), Victor Enthoven, "Veel vertier.' De Verenigde Oostindische Compagnie in Zeeland, een economische reus op Walcheren," Archief. Mededelingen van het Koninklijk Zeeuwsch Genootschap der Wetenschappen (1989), 49-127, and Hans Bonke and Katja Bossaers, Heren investeren. De bewindhebbers van de WestFriese Kamers van de voc (Haarlem: Regionale Geschiedbeoefening Noord-Holland, 2002). 
followed a similar model. Thus, while the companies formally remained private institutions, informally they were strongly integrated with the state on an organizational and personal level. Appendix 1 shows this more concretely by tracing the West Indian connections of members of the Amsterdam Admiralty Board. Among naval administrators, many had either been major investors (hoofdparticipanten) or directors of the WIC, or were moving into West Indian careers. Sometimes these state and semi-private functions overlapped directly. But even where they did not, it is hard to maintain the image of a West-India interest that was pristinely commercial, disconnected from state policies. A letter written during the Fourth Anglo-Dutch War to the Governor General in Suriname by the highest official of the Amsterdam Admiralty Board, Fiscal Advocate Johan Cornelis van der Hoop, who had himself recently given up his position as director of the Suriname Company, underlines that those trading places between state and company, even as late as the 1780 s when according to Emmer all hopes for maintaining a Dutch empire in the West were long lost, took with them their former attachments:

This I can testify, that I would not have left [the Suriname Company] if the circumstances of war had not hindered my own prospects concerning the colony, forcing me to abandon the hope of seeing it again soon in the state of affluence in which it can be. Nonetheless, Your Honor will possibly have already been informed, that I can indeed retain my attachment to the Colony, be active in it, and will especially work to bring any help and improvement to your conditions that are within my powers. ${ }^{18}$

Close connections between state and companies meant that the formal distinction between state strategies and commercial strategies overseas could be easily bridged in times of need. Of course, there were also important disadvantages for long-term power projection that were inherent to the brokerage forms of state and merchant cooperation that underlay the Dutch Atlantic empire. The most important of these is that different towns and provinces could use their influence over the federal state and the companies to favor the interests of "their own" merchants. This problem had a particular impact in the Atlantic, where Zeeland and Amsterdam often clashed vehemently, to the detriment of the long-term capacity of the WIC to hold its ground. Private merchants could and did use these divisions to undercut the monopoly of both the first and the second wIC, leading to the situation after 1734 when the wIC had lost all of its

18 Dutch National Archive, The Hague, Admiraliteitscolleges XxxIx, Van de Hoop, 1524-1825, no. 54, p. 167. Letter by Van der Hoop to Governor General Texier in Suriname, 7 April 1782. 
former monopoly trading rights. Rather than leading to the abolition of the WIC, this meant that the Company was reduced to only one of the two core functions that had been assigned to it and its predecessor right from the start. Having lost most of its commercial functions, the WIC continued as a brokerage institution renting out protection on the African coast, and administrating Dutch foreign possessions in exchange for the right to levy a tax on West Indian commerce..$^{19}$ As will be shown in the following sections, the legal division between state territoriality at home and company territoriality overseas did not prevent the States General from intervening in West Indian affairs when the core interests of Dutch trade in the Atlantic were at stake.

\section{The Grand Design and the Loss of Dutch Brazil}

The first phase of Dutch territorial expansion was directly subordinate to the struggle between the emergent Dutch Republic and the Habsburg Empire. ${ }^{20}$ This context also heavily influenced the Dutch position on enslaved labor as a core institution of the Atlantic economy. During the Dutch Revolt, the abhorrence of slavery as a particularly Spanish crime against the natives of the Americas had formed one of the master-themes of the leyenda negra employed in anti-Habsburg propaganda. When venturing into the Americas, the Dutch for a time cultivated the illusion of a natural alliance between themselves and the natives, founded on the common experience of Spanish bondage. ${ }^{21}$ Of course, these fantasies were never innocent, and Dutch attitudes to slavery changed dramatically as soon as the prospects of expansion became more concrete. Being drawn into the slave trade by a series of more or less coincidental actions of private merchants, very soon the Dutch came to appreciate the enslavement of non-Europeans on a more systematic basis as a way to build their empire. ${ }^{22}$ However, problems connected to the capture and control of forced labor, including resistance and mutiny by the enslaved themselves, limited the options for Dutch empire-builders.

19 Henk den Heijer, Goud, ivoor en slaven. Scheepvaart en handel van de Tweede Westindische Compagnie op Afrika, 1674-1740 (Zutphen: Walburg Pers, 1997), 299 ff.

20 Jonathan I. Israel, The Dutch Republic and the Hispanic world 1606-1661 (Oxford: Clarendon Press, 1982).

21 Benjamin Schmidt, "Exotic Allies. The Dutch-Chilean Encounter and the Failed Conquest of America," Renaissance Quarterly vol. $5^{2}$ (1999): 440-473.

22 Johannes Menne Postma, The Dutch in the Atlantic Slave Trade 1600-1815 (Cambridge: Cambridge University Press, 1990), $10 \mathrm{ff}$. 
The Groot Desseyn was the name of a failed attempt—in several waves—by the Dutch to create an Atlantic Empire based on acquiring slave fortresses in Africa and sugar plantations in Brazil. The acquisition of labor played out at three levels closely connecting the capture of land in the Americas, slave trading fortresses in Africa, and the mobilization of soldiers from Europe. The tactical choices behind the large scale incursion into the Iberian Atlantic were the outcome of a debate between the States of Zeeland and Holland about how to engage militarily and economically in the Atlantic. The difference of opinion largely rested on the choice between a frontal attack, preferred by Amsterdam, and a more cautious incursion via the Guianas advocated by Willem Usselinx representing Zeeland. The States of Holland won this debate, which in turn led to a large scale mobilization of forces to support the plan. While initially relying on European workers, the Dutch soon learned that they needed the people they encountered overseas if they were to settle in the Americas successfully. While initially opting for friendly relations, the Dutch increasingly began to rely on force and enslavement. The resulting conflict contributed to the failure of the Dutch to hold on to Brazil. ${ }^{23}$

On a European level the Groot Desseyn had immediate repercussions for the mobilization of military men from all over North Western Europe. The first wave of the Groot Desseyn commenced in 1624 and included the ravenous capture of Bahia where soldiers under Dutch command raped and pillaged in a drunken frenzy. Brazil became a flashpoint in Hispano-Dutch warfare and the widespread reporting on the events on both sides mimicked the central themes of the conflict. ${ }^{24}$ The importance of the Dutch challenge to the Iberian powers is illustrated by the grand revenge undertaken by the Spanish forces. The Spanish troops began their counter attack in the Southern Netherlands by successfully laying siege to Breda to delay a Dutch release party for the soon to be besieged forces in Bahia. Then, the Portuguese and Spanish combined their forces to mobilize the largest army that ever had crossed the Atlantic. ${ }^{25}$ These

23 Den Heyer, Geschiedenis van de wic, 69-73.

24 Yolanda Rodríguez Pérez, "Wijze Indianen, Barbaarse Hollanders. De beeldvorming van Nederlanders en Indianen in de Spaanse literatuur van de Gouden Eeuw," De Zeventiende Eeuw vol. 21, no. 1 (2005): 99-111, and Michiel van Groesen, "Lessons Learned. The Second Dutch Conquest of Brazil and the Memory of the First," Colonial Latin American Review vol. 20, no. 2 (2011): 167-193.

25 Jan Dirksz Lam, Expeditie naar de Goudkust: het journaal van Jan Dircksz Lam over de Nederlandse aanval op Elmina, 1624-1626, edited by Hendrik Jacob den Heijer (Zutphen: Walburg Pers, 2013), 33; Mark Meuwese, Brothers in Arms, Partners in Trade. DutchIndigenous Alliances in the Atlantic World, 1595-1674 (Leiden/Boston: Brill, 2012), 35; Den Heijer, De geschiedenis van de WIC, ${ }^{8}{ }^{8}-39$. 
were only the opening moves of what would become a global battle between the Iberians and the Dutch. It is estimated that a total of 67,000 men were hired by the WIC between 1623 and 1636 , most of these sailors and soldiers. ${ }^{26}$

In 1625 , the wIC initiated a plan to strike all around the Atlantic, with the main force serving as a release party in Brazil. This army was then to be split up to go to Africa and the Caribbean. In the event, however, the Dutch were confronted with the severe limitations of relying solely on European soldiers and sailors. On the Atlantic crossing 2,00o sailors and soldiers died, and the release of Bahia failed. Nevertheless, the expeditionary force split to make two attacks, one on Puerto Rico and one on Elmina. ${ }^{27}$ The Puerto Rico expedition failed, and the commander could not execute the remainder of his orders because the now restless and mutinous crew forced the squadron to sail back to the Republic. The attack on the Gold Coast failed as well. Here the usefulness of indigenous forces was made painfully clear to the Dutch. While resting, the Dutch sailors and soldiers suffered a surprise attack by African soldiers under Portuguese command, "cutting their heads like chickens" leaving 441 men dead. ${ }^{28}$

Undeterred by the defeat the Dutch managed to mobilize a second wave of attacks. In 1629 7,000 soldiers and sailors were sent to Brazil. The encounters with African and Indigenous soldiers taught the Dutch that they needed to recruit indigenous forces to fight their battles for them. The Dutch tried to break the alliance between the Indigenous fighters and the Portuguese. The promise of freedom was an obvious choice for the Dutch when it came to acquiring the goodwill of Portuguese unfree and colonized subjects. To bring the Indigenous Brazilians to their camp, the WIC in their Order of Government of 1629 proclaimed the Indigenous Brazilians to be free subjects. The WIC affirmed that all Africans and Indigenous Brazilians would be freed if they had

26 Filipa Ribeiro da Silva, Dutch and Portuguese in Western Africa. Empires, Merchants and the Atlantic System, 1580-1674 (Leiden/Boston: Brill, 2011), 106-107; Bruno Romero Ferreira Miranda, Gente de Guerra. Origem cotidiano e resistência dos soldados do exército da companhia das índias ocidentais no Brasil (1630-1654), unpublished Ph.D. Dissertation, Leiden University, 2011, https://openaccess.leidenuniv.nl/handle/1887/18047. While it is usually assumed by Dutch historians that the possibility to attract immigrant labor for the army and the fleet precluded impressment as a central form of labor recruitment, there is sporadic evidence for impressment. More importantly, the widespread practice of trapping sailors in debt forcing them to serve the voc, wIC and navy, can also be viewed as a forced labor practice. Matthias van Rossum, Werkers van de wereld. Globalisering, maritieme arbeidsmarkten en de verhouding tussen Aziaten en Europeanen in dienst van de voc, unpublished Ph.D. Dissertation, Free University Amsterdam, 2013. Mark Meuwese, Brothers in Arms, 36 .

28 Lam, Expeditie naar de Goudkust. 
"ran away from their masters to our side during the recent war." ${ }^{29}$ Africans, who escaped enslavement under the Portuguese did join the Dutch, but only on the condition that they would be free. ${ }^{30}$ The promise of freedom was however difficult to keep for the Dutch.

In Brazil the fear that Indigenous Brazilians would defect from the Dutch was constant, and this fear informed how the state attempted to regulate the exploitation and use of the Indigenous. The wic had to repeat time and again to its European subjects that Brazilians should not be enslaved. These ordinances were published to prevent conflicts with the Indigenous, who in Portuguese times had been paid (about half the customary European wages) rather than enslaved. Good relations with the indigenous were predicated on the Dutch paying ample respect to them, as well as the tribute that the Dutch delivered to the Indigenous leaders. This made the Indigenous unsuited for exploitation on the plantations. The ensuing strategy of reliance on Indigenous troops was successful for the colonists for a limited number of years. In the late 1630 s the Indigenous forces supplied considerable number of people to the WIC expeditions, border patrols, counter insurgency and the successful attempt to fend off the landing of the Spanish forces in Brazil. They later were instrumental in the WIC's capture of Luanda and São Tomé in $1641 .{ }^{31}$

However, there were severe limits to the strategy, connected to the tensions between relying on the promise of freedom on the one hand, and the building of slave-based plantation economies on the other. In the first waves of the Dutch Atlantic expansion the Caribbean and Brazilian incursions were intricately linked. The same could be said for the supply of forced indigenous labor. The lack of slave imports prompted the Dutch colonists on St. Eustatius to import enslaved Amerindians. Lack of laborers made the colonists look for places to enslave them, both on the Caribbean Islands and on the Guiana coast. There they notoriously kidnapped as many as 80 people on one occasion. ${ }^{32} \mathrm{~A}$ debate was held amongst the wIC directors about the possibility of engaging in the trading of enslaved Amerindians in the Amazon delta. The trading of Amerindian slaves was a common practice of the Portuguese from Maranhão to Pernambuco. When the Dutch took over this area they began to export the enslaved from Amazonia to Maranhão to Spanish America and the

29 Dutch National Archive, The Hague, Oude Westindische Compagnie, inv.nr. 8, letter by the Heeren XIX, 1 August 1635. cited in: Mark Meuwese, Brothers in Arms, 149.

$30 \quad$ Ibid., 128.

31 Ibid., 154-162.

32 Cornelis Goslinga, The Dutch in the Caribbean and on the Wild Coast 1580-1680 (Assen: Van Gorcum, 1971), 263. 
Caribbean. After the wIC securely took Marnahão from the Portuguese, Dutch traders of indigenous slaves arrived in Barbados to sell their human cargoes. While contrary to the formal wIC policy that granted freedom to the indigenous, in practice these regulations were not upheld. ${ }^{33}$ In the 1640 os the Dutch actively participated in the Caribbean market for enslaved Amerindians. ${ }^{34}$ In Brazil itself, once the use of the Indigenous for military expeditions declined, they were mobilized to work as "wood-cutters, cattle ranchers, and cart-drivers," crucial functions for the running of sugar mills. However, the field work was done by enslaved Africans. In the salt pans the Dutch did employ Indigenous Brazilians, but they were deemed most important to produce food to sustain the enslaved Africans on the plantations. ${ }^{35}$

After the initial success in recruiting Indigenous forces, the continuing enslavement of them partly explains why the Dutch were to lose control of important areas in Brazil in the following years. The conflicts over indigenous enslavement and the high death toll among the Indigenous fighters when the Dutch undertook their assault on Luanda, turned the relation with the Indigenous Brazilians sour. Around 1642 a smallpox epidemic strained the relations further. The Dutch not only became associated with the spread of the disease, company officials also decided to use enslaved Indigenous Brazilians to replace the workers who had died. ${ }^{36}$ The traditional Portuguese Brazilian view has been that the insults from Jews and Protestants against the religious practices of the Indigenous united them with the Catholic plantation owners against the Dutch. ${ }^{37}$ According to a recent study by Mark Meuwese the wIC was "forcibly expelled" from Maranhão and Ceará in 1643-1644 because of an uprising that was triggered by the exploitation of indigenous workers by WIC personnel. ${ }^{38}$ From 1645 onwards the simultaneous and combined uprisings by Portuguese colonists and Indigenous Brazilians spelled the end of the Dutch adventure in Brazil. ${ }^{39}$

The loss of the two provinces served as an example and the Dutch began to lose their will to invest in the retaking of lost possessions, although it took nine

33 L.A.H.C. Hulsman, 'Nederlands Amazonia: Handel Met Indianen Tussen 1580 en 1680', Ph.D. dissertation, University of Amsterdam Amsterdam, 2009, 138-139, http://dare.uva $. \mathrm{nl} / \mathrm{record} / 316229$.

$34 \quad$ Ibid., 138.

35 Mark Meuwese, Brothers in Arms, 157-158.

36 Ibid., 166-169.

37 João Capistrano de Abreu, Chapters of Brazil's Colonial History, 1500-180o, trans. Arthur Brakel (Oxford: Oxford University Press, 1997), 87.

38 Mark Meuwese, Brothers in Arms, 189.

39 C.R. Boxer, The Dutch in Brazil, 1624-1654 (Oxford: Clarendon Press, 1957), 159-171. 
more years to really end the Dutch hold over its last colonial possession in Brazil. In the face of impending defeat the WIC, the states of Zeeland, and Holland as well as the States General started to turn in on each other, all trying to protect the part of this project that was most valuable to them. Amsterdam's priority was to keep the sugar trade going, regardless of the nationality of the producers. Zeeland however profited from privateering operations along the coast, for which Zeeland investors needed military backup and a continuation of hostilities. ${ }^{40}$ In 1648 the States General mustered one last expedition to save what remained of Dutch Brazil, but this ended in defeat in 1649 . When supplies began to run low and the commander of the fleet was confronted by a mutiny the decision was made not to complete orders and sail back to the Republic. In the following years the power of the Dutch shrank, until their last stronghold in Recife fell in $1654 .^{41}$ Even in these years, the States General continued to provide substantial financial and material support to the WIC efforts to maintain its Brazilian strongholds. The eventual loss of Brazil was compensated for the Dutch by gains in Asia, as well as the offer of reparations to be made by the Portuguese for the loss of the colony and its property. ${ }^{42}$

\section{Continued Expansion}

While the grand design and the subsequent development of Brazil as a Dutch colony failed, the Dutch did not retreat from the Atlantic world. The Dutch came to focus primarily on (slave) trading in what has been called the second Atlantic economy. In this second system the territory was smaller, although the Dutch presence on the African coast was substantial. Based on its territorial

$40 \quad$ H.J. den Heijer, "Het recht van de sterkste in de polder. Politieke en economische strijd tussen Amsterdam en Zeeland over de kwestie Brazilië, 1630-1654," in D. Bos, M.A. Ebben and Henk te Velde eds., Harmonie in Holland. Het poldermodel van 1500 tot nu (Amsterdam: Bert Bakker, 2007), 72-92.; W.J. van Hoboken, Witte de With in Brazilië, 1648-1649 (Amsterdam 1955), 6-9, 18-24.

41 Bea Brommer, Henk den Heijer, and Jaap Jacobs, Grote atlas van de West-Indische Compagnie/Comprehensive atlas of the Dutch West India Company. I, De oude WIC 16211674/The old WIC 1621-1674 (Voorburg: Asia Maior, 2011), 158.

Cátia Antunes, "Oost voor West en West voor Oost. De Nederlands-Portugese koloniale interactie in de zeventiende eeuw," in Alicia Schrikker and Thomas Lindblad eds., Het verre gezicht: Politieke en culturele relaties tussen Nederland en Azië, Afrika en Amerika (Franeker: Van Wijnen, 2011), 35-48; Evaldo Cabral de Mello, De Braziliaanse affaire. Portugal, de Republiek der Verenigde Nederlanden en Noord-Oost Brazilië, 1641-1669, trans. Catherine Barel (Zutphen: Walburg Pers, 2005), 61-82. 
position both on the African coast and in the Caribbean the Dutch were able to acquire a central role in the trans-Atlantic slave trade only second to Portugal until $1675 .^{43}$ It has to be kept in mind how important the territorial requirements were that underpinned the Dutch Atlantic after the fall of Brazil. The slave forts became central to Anglo-Dutch confrontations beyond European waters in the Western hemisphere. When adding to this the time between the loss of Brazil and the acquiring of Suriname was no more that thirteen years, it can easily be argued that the Dutch continued to engage almost uninterruptedly in territorial conflicts in the Atlantic throughout the seventeenth century. This should come as no surprise in a period that was characterized by almost continuous engagement in great-power struggle for the Dutch. ${ }^{44}$

The first steps into the slave trade by the Dutch were taken by private traders, before the development of the monopoly companies. These private traders had slave trading as part of their wider trade portfolio, servicing Spanish and Portuguese demand in the Caribbean and Brazil. These private voyages were limited in number, employing slave trading knowledge acquired from the Iberian precedent in the Southern Atlantic. ${ }^{45}$ After 1635 the WIC got a firmer grip on the slave trade, but private traders did continue their activities. In the period between 1580 and 1674 private traders organized at least 45 per cent of the Dutch slave trade. As Antunes and Ribeiro da Silva argue for the period, only twelve per cent of the Dutch slaving voyages at the time can be confirmed to have been organized by the WIC, of the remaining 43 per cent it is unclear if they were either private or WIC voyages. ${ }^{46}$ Private entrepreneurs, especially from Amsterdam, thus laid an important foundation under the Dutch engagement with the Atlantic world. The WIC was one of the actors, and would increase in importance over the following decades, relying upon the military foundation on which private trade rested.

43 Jan de Vries, "The Dutch Atlantic Economies," in Peter A. Coclanis ed., The Atlantic Economy during the Seventeenth and Eighteenth Centuries: Organization, Operation, Practice, and Personnel (Columbia, South Carolina: University of South Carolina Press, 2005), 1-29.

44 Maarten Prak, The Dutch Republic in the Seventeenth Century (Cambridge: Cambridge University Press, 2005), 27 ff.

45 Catia Antunes and Filipa Ribeiro da Silva, "Amsterdam Merchants in the Slave Trade and African Commerce, 1580s-1670s," Tijdschrift Voor Sociale En Economische Geschiedenis vol. 9, no. 2 (2012):3-30; Wim Klooster, "Het begin van de Nederlandse slavenhandel in het Atlantisch gebied," in Maurits Ebben, Henk den Heijer and Joost Schokkenbroek eds., Alle streken van het kompas. Maritieme geschiedenis is Nederland (Zutphen: Walburg Pers, 2010), 249-262.

46 Antunes and Ribeiro da Silva, "Amsterdam Merchants in the Slave Trade and African Commerce, 1580s-1670s." 
With regards to the regular trade in enslaved Africans, two tracks of engagement developed. The Dutch primarily shipped slaves to work on Dutch plantations. They did this both for Brazil as well as Suriname and the smaller Guiana colonies. After the second Anglo-Dutch War there was also a period when the Dutch Caribbean island of Curaçao became the main destination for Dutch slave ships. These shipments of African captives were not primarily destined to work on Dutch plantations, but were to be sold to the Spanish, as well as French and British colonists. This lasted until the War of the Spanish Succession when the Dutch plantation colony Suriname became the primary destination of the ships. ${ }^{47}$ The servicing of non-Dutch colonial enterprises not only took place on Dutch ships. Especially in the eighteenth century the Dutch stronghold of Elmina was where the slaves were sold to Portuguese and other merchants. ${ }^{48}$

After the loss of Brazil and during the transition into the second Atlantic system, state intervention in the Atlantic region became inextricably linked to the competition between the Dutch state and England as the rising Atlantic power. The first Anglo-Dutch War in the mid-1650s, combined with a weakening of Spanish power in the region, had allowed the wIC to move into the African slave trade on a large scale, and to become a subcontractor for the asiento in $1662 .{ }^{49}$ However, the simultaneous growth of the English role in the slave trade led to increasing clashes along the African coast. In 1661, an English Royal Adventurers expedition captured the WIC fortress St Andries in the Gambia estuary. In 1663, Charles II sent a navy squadron to protect English interests in the slave trade, leading to further clashes with the wic. ${ }^{50}$ Characteristically, the wIC turned to the States General for help. In 1664, the "Highly Esteemed Gentlemen" decided to send twelve war-ships headed by the Republic's most able fleet commander Michiel de Ruyter to recapture WIC fortresses on the Guinean coast. ${ }^{51}$ De Ruyter's seventeenth-century biographer Gerard Brandt described the reasoning behind this decision:

They [the States General] judged that such violence was insufferable, and had to be stopped with valiance and force, both because of the

The Trans-Atlantic Slave Trade Database (Atlanta, Georgia, 2008), http://www.slavevoyages .org/.

48 Den Heijer, Goud, ivoor en slaven, 366.

49 Postma, The Dutch in the Atlantic Slave Trade, 33, and J.R. Jones, The Anglo-Dutch Wars of the Seventeenth Century (London/New York: Longman, 1996), 35.

$5^{\circ}$ Gijs Rommelse, The Second Anglo-Dutch War, (1665-1667): International Raison d'état, Mercantilism and maritime strife (Hilversum: Verloren, 2006), 89-91.

51 Ibid, 106-108. 
consequences thereof for the prestige of other far-away dominions and possessions, and for other reasons. They understood, that they had to restore the West India Company (which had provided the State with great services at various occasions) in their possessions along the coasts of Africa and Guinea, and to help them keep everything else they possessed there; both for the reputation and respectability of the state, and for the large trade that in those regions was conducted with considerable advantages. ${ }^{52}$

De Ruyter's success in saving the Dutch slave fortresses formed the direct prelude to the Second Anglo-Dutch War, which defined the shape of the Dutch Atlantic empire for the remainder of the seventeenth century and the entirety of the next. During this war, the English captured the Dutch colonies of New Netherland and Suriname, consolidating the small territorial empire that from now on was focused completely on the African coast and the Caribbean colonies that provided the Dutch with their own overseas plantation system and a permanent bridgehead into the wider Atlantic trade.

The Dutch learned much about the enslavement of Africans and the trade in these captive workers during their engagement in Brazil. ${ }^{53}$ With this knowledge they were able to reinvent their empire. As has been noted, the new system was based on the capture of West African strongholds in the late 1630 s and early 1640 s and expansion in the Caribbean and the Guiana Coast. But the continuation of Dutch control against the threats by competitors defined much of the Atlantic conflicts in which the Dutch engaged. Part of this was the consolidation of its African domains, which resulted in a large boom in the Dutch slave trade. In the period between 1674 and 1680 many enslaved Africans were exported from Elmina. ${ }^{54}$ The territorial expansion into the Guianas in 1667 shows that the Dutch continued to hold on to their expansionist vision for the building of a productive empire based on enslaved African labor acquired through its forts of the African coast as well as plantation colonies on the Guiana Coast. These state funded conflicts catered to the interests of private actors from Dutch cities who invested in trade, production, and war, thus further entangling imperial rivalry with the imperatives of the Atlantic slave trade.

$5^{2}$ Gerard Brandt, Het leven en bedryf van den heere Michiel de Ruiter, Hertog, Ridder, \&c. L. Admiraal Generaal van Hollandt en Westvrieslandt (Amsterdam: Wolfgang, Waasberge, Boom, Van Someren en Goethals, 1687), 292. 


\section{Imperial Consolidation}

Rather than a steady decline, as suggested by Emmer, or, as Jan de Vries has argued, that the Dutch shifted their attention to the role of Atlantic middlemen after the loss of Brazil, the Dutch presence in the Atlantic should be characterized as imperial consolidation on a modest yet solid footing. The Second Anglo-Dutch War was a success for the Dutch in that they simultaneously took a definitive hold of their position on the slave trading African coast and acquired and consolidated their holdings on the Guiana Coast. The AngloDutch naval alliance that was concluded after the Third Anglo-Dutch War (1672-1674) did not end state involvement in favor of Atlantic trade. While at the height of Dutch power at sea in the mid-165os, naval convoying for the protection of trade had been primarily provided for European destinations with an emphasis on the protection of the Baltic "mother trade," eighteenthcentury naval assistance became more and more directed towards the protection of long-distance trade. Decades long low-intensity warfare against the North-African privateering states of Sale (Morocco) and Algiers became key priorities of the Amsterdam Navy Board, as shown in Table 4.1 which sums up the total convoying activities conducted from Amsterdam in a representative year in the mid-eighteenth century. ${ }^{55}$

TABLE 4.1 Convoying ships and cruisers sent out by the Amsterdam Admiralty Board, 1738

\begin{tabular}{llcc}
\hline Name ship & Destination & $\begin{array}{c}\text { Crew } \\
\text { size }\end{array}$ & Total costs $(f)$ \\
\hline Dolphijn & Morocco and the Mediterranean & 151 & 56,594 \\
Spiegelbos & Morocco and the Mediterranean & 150 & 50,781 \\
Brederode & Mediterranean & 271 & 102,554 \\
De Brack & Mediterranean & 100 & 38,563 \\
Hartekamp & Morocco & 150 & 49,324 \\
Westerdijkshorn & West Indies & 201 & 78,517 \\
Beschermer & West Indies & 201 & 75,652 \\
& & 1,224 & 451,985 \\
\hline
\end{tabular}

SOURCE: DUTCH NATIONAL ARCHIVE, THE HAGUE, ARCHIEF GENERALITEITSREKENKAMER, NO. 548 .

55 On the general development of the Dutch naval intervention in this period, see J.R. Bruijn, The Duch Navy of the Seventeenth and Eighteenth Centuries (Columbia, sc: University of South Caroline, 1993). 
The employment of state force also characterized the consolidation of the Dutch Empire on the other side of the Atlantic. Without the combined assistance from the WIC and the state in providing slaves, soldiers and money, the Dutch exploits on the Guiana coast would have been doomed. On some occasions the colonization efforts did not get state backing. Those expeditions failed, invariably ending in the decimation of the colonists involved. ${ }^{56}$ Only when fortresses were built and slave ships provided laborers, could colonization attempts survive.

In the second Dutch Atlantic system, based on plantation production and transit-trade in the Caribbean, the relative numbers of sailors, soldiers and plantation laborers changed fundamentally. The armies sent across the Atlantic became smaller, while the size of the agricultural workforce increased drastically. The Dutch-French assault on St. Eustatius in 1666 was undertaken by at most a few hundred men. The grand assault on English power in the Caribbean by Abraham Crijnssen was undertaken by only 3 frigates, $75^{\circ}$ sailors and 224 soldiers, a fraction of what was deployed to fight the Iberians in Brazil and West Africa. Still it managed to wrest Suriname from English power and continue to assault a number of other colonies as well. ${ }^{57}$ From the end of the Second Anglo Dutch War onwards the Dutch Atlantic territory was largely consolidated around four Guiana plantation colonies, Berbice, Demerara, Essequibo and Suriname, and the two islands Curacao and St. Eustatius. While not large compared to the other European territories in the Americas, these colonies were strategically located in the fast expanding world of Atlantic production. The Guianas produced primarily sugar, and in the eighteenth century also the boom product of coffee. The islands, on the other hand, functioned as nodal points for trade. ${ }^{58}$

$5^{6} \quad$ Henk den Heijer, “'Over warme en koude landen'. Mislukte Nederlandse volksplantingen op de Wilde Kust in de zeventiende eeuw," De Zeventiende Eeuw vol. 21, no. 1 (2005): 79-90; G. van Alphen, Jan Reeps en zijn onbekende kolonisatiepoging in Zuid-Amerika, 1692 (Assen: Van Gorcum, 1960); Kim Isolde Muller (ed.), Elisabeth van der Woude, Memorije van't geen bij mijn tijt is voorgevallen: met het opzienbarende verslag van haar reis naar de Wilde Kust, 1676-1677 (Amsterdam: Terra Incognita, 2001).

57 Goslinga, The Dutch in the Caribbean, 395-399.

58 Gert Oostindie and Jessica Vance Roitman, "Repositioning the Dutch in the Atlantic, 1680-180o," Itinerario vol. 36, no. 2 (2012): 129-160; Wim Klooster, Illicit Riches: The Dutch Trade in the Caribbean, 1648-1795, 1995; Linda Marguerite Rupert, Creolization and Contraband: Curaçao in the Early Modern Atlantic World (Athens: University of Georgia Press, 2012); Johannes Postma, "Suriname and Its Atlantic Connections, 1667-1795," in Riches from Atlantic Commerce: Dutch Transatlantic Trade and Shipping, 1585-1817, 
In terms of their political organization, these colonies reflected the large role of federal and private bodies in the structure of the Dutch state at home. Suriname is a case in point. Conflicts over strategy between the province of Holland and Zeeland played a large role in the run up to the conquest of the colony, and in the first decade and a half of its existence, the new Dutch territory overseas was run by the States of Zeeland, with the States General taking upon itself responsibility for the defense of the colony. In 1683, control of Suriname was turned over to the new-founded Suriname Society, with the WIC, the city of Amsterdam and the ruling class family Van Aerssen-Van Sommelsdijck each taking an equal share. Thus, the execution of colonial rule rested on the same private-state cooperation that underlay the entire Dutch overseas empire. ${ }^{59}$

Suriname soon developed into the largest production center for tropical goods under Dutch control. The colony was envisioned as a new Brazil and a second chance to set up large scale plantation production. ${ }^{60}$ For the Dutch the major difference between Suriname and Brazil was that the Portuguese had not previously settled there, and there was no similar relationship between the colonizing Europeans and the indigenous Caribs and Arawaks as there had been with the native Brazilians. The English colonizers from whom the Dutch took the colony in 1667-8 did not have institutions by which the indigenous worked for them on a large scale, had forms of representation in government, or were engaged in the military apparatus of the colony. Under Dutch rule of Suriname some Indigenous were initially held as slaves while other groups made alliances and served as auxiliaries. The relation between the colonizers and the colonized turned sour more quickly than in Brazil. During the conflicts the Dutch took measures to effect a stricter separation between colonists and the Indigenous. In 1679,

Johannes Posma and Victor Enthoven (eds.), The Atlantic World, vol. 1 (Leiden / Boston: Brill Academic Publishers, 2003), 287-322; Victor Enthoven, "'That Abominable Nest of Pirates': St. Eustatius and the North Americans, 1680-1780," Early American Studies: An Interdisciplinary Journal vol. 10, no. 2 (2012): 239-301.

Cornelis Ch. Goslinga, The Dutch in the Caribbean and in the Guianas, 1680-1791, Anjerpublikaties 19 (Assen, Netherlands: Van Gorcum, 1985); G.W. van der Meiden, Betwist Bestuur: een eeuw strijd om de macht in Suriname, 1651-1753 (Amsterdam: Bataafsche Leeuw, 2008), 10-16.

6o Otto Keye, Beschryvinge van het heerlijcke ende gezegende landt Guajana, waer inne gelegen is de seer voorname lantstreke genaemt Serrenamme (The Hague: Henricus Hondius boekverkooper in de Hofstraet, 1667). 
as a result of the sustained attacks, many plantations were abandoned and further colonization was seriously endangered. ${ }^{61}$

To prevent a repetition of the Brazilian debacle, Governor Heinsius, a veteran from Brazil was sent to the colony. ${ }^{62}$ The colonists themselves responded to the Indigenous threat with mass executions. One of them reported "we have now hanged about 30 of the rascals, and caught and shot an equal number." 63 The irregular militias of the colonists were not sufficient to subdue the indigenous attacks, and the States General intervened by supplying armed forces and building fortresses. By 1680 the Dutch went on the counter offensive, with the capture of the indigenous stronghold Karassobo being of great military importance. ${ }^{64}$ They continued burning indigenous villages. In one attack they captured " 82 Indians, both men, women and children, and five Negroes." The majority of the captives were hanged in the forest. ${ }^{65}$ In the closing years of the war two fortresses, Fort Para and Fort Sommelsdijck, were constructed as strongholds against these indigenous attacks. The colonists began to take steps to appease the Amerindians, while shifting the brunt of plantation labor even further towards enslaved Africans. The Dutch finally managed to gain lasting peace by banning the colonists from trading with the Indigenous (a permanent source of conflict), letting the Dutch governor marry the daughter of one of the Indigenous leaders, organizing the regular payment of tribute in the form of an Indiaas Cargasoen and maybe most importantly by banning the enslavement of Amerindians. Over the years indigenous enslavement in the colony dropped from five hundred "red" slaves to less than $60 .{ }^{66}$

From the moment the Surinamese colony was secured, the Dutch plantation system began to experience steady expansion. To sustain the constant stream of enslaved Africans, the colonists could not rely on private merchants alone. While initially the governor had allowed interlopers to act as suppliers, plantation owners wanted a more regulated supply of captive workers. A petitioning colonist argued: "The supply of negroes by private traders, as has been the practice so far, is to the detriment of the planters, because this does not give them sufficient time to pay their debts, and the planter cannot sustain

61 R. Buve, "Gouverneur Johannes Heinsius, de rol van Van Aerssens voorganger tijdens de Surinaams-Indische Oorlog, 1678-1680," Nieuwe West-Indische Gids vol. 45 (1966): 14-26.

62 Ibid.

63 Zeeuws Archief, Staten van Zeeland, 2035 no. 326.

64 Hulsman, "Nederlands Amazonia," 171.

65 Zeeuws Archief, Staten van Zeeland, 2035 nos. 445/446.

66 Karwan Fatah-Black, "Suriname and the Atlantic World, 1650-1800," Ph.D. thesis, Leiden University, 2013, 172. 
himself." ${ }^{\prime 67}$ To remedy this the Dutch wIC, which was at the same time a trading company and partner in the administration of the colony, was to step in and secure slave shipments. Taking an interest in the long-term development of a stable colony, the WIC simultaneously provided credit to the planters who could not pay for their captive workers on delivery. In this very concrete way the company was called into action to support the colonial project. However, private traders continuously infringed on the monopoly, and interloping became a major phenomenon. ${ }^{68}$ At the end of the seventeenth century the WIC again began to threaten to stop the slave trade because the company was supplying endless lines of credit, without the planters repaying their debts. It took private initiative from Surinamese colonists to entice the WIC to return to the slave trading business. ${ }^{69}$

This combination of functions of the wIC, which acted at one and the same time as partner in colonial administration, supplier of (enslaved) labor power and creditor, might have been a reason why liberalization of the Dutch slave trade came rather late compared to the other north European competitors. In the case of the Dutch, the state chartered company continued its exclusive position until 1730, while the French and British had already opened the trade to private entrepreneurs in the seventeenth century. The WIC at the time had been running at a loss, but because of the company's centrality to Dutch power and slave trading in the Atlantic the States General continued to subsidize it on a regular basis. In the late 1720 s debate ensued between the WIC directors and free traders about the liberalization of the trade. The company directors argued they were in the best position to supply the plantation colonies with enslaved Africans. The private traders, however, were accommodated by the States General by a partial opening of the slave trade. From 1730 onward free traders were able to buy licenses from the WIC, and the company retained its exclusive right to the slave trade to Suriname and the other Guiana colonies. In 1734 the free traders won another victory over the monopoly company, which was forced to open up the Gold Coast to the private traders. Finally, in 1738, the WIC was forced to let go of its exclusive right to the slave trade in Suriname and the Guianas. ${ }^{70}$

67 Zeeuws Archief, Staten van Zeeland, 2035 no. 129. Petition by inhabitants of Suriname of March 1669 .

68 Rudolf Paesie, Lorrendrayen op Africa. De illegale goederen-en slavenhandel op West-Afrika tijdens het achttiende-eeuwse handelsmonopolie van de West-Indische Compagnie, 170o1734 (Amsterdam: De Bataafsche Leeuw, 2008).

69 Fatah-Black, "Suriname and the Atlantic World," 180-184.

70 Postma, The Dutch, 201-206. 
Although the company directors were pessimistic about the future of the company after the loss of its right over the slave trade, the company continued for another 61 years. ${ }^{71}$ From Elmina the WIC was selling on average between one thousand and two and a half thousand slaves directly to the Dutch free traders until the collapse of Dutch power in the Fourth Anglo-Dutch War. ${ }^{72}$ The WIC also sold numerous slaves to non-Dutch ships from their strongholds on the Gold Coast. Henk den Heijer estimates this amounted to as many as fifteen hundred to two thousand slaves per year. ${ }^{73}$ The Dutch private traders used Elmina to amend their shipments in case they failed to acquire enough slaves along the coast, and foreign traders could use Elmina as a European stronghold and slave market. In exchange for Brazilian tobacco, gold and other products the Dutch provided slaves to arriving ships or sold the right to sail to Elmina's subsidiary fortresses and outposts in exchange for gold or tropical products. ${ }^{74}$

Dutch military activities in the Atlantic world of the eighteenth century concentrated on protecting the plantation complex. This included the building and manning of fortresses, the convoying of merchant vessels and the long drawn out battles against slave uprisings and conflicts with maroon communities. In all these activities the States General consistently intervened to support the colonial enterprises, even investing in military defense when the formal holders of the jurisdiction (such as chartered companies) proved unwilling or unable. For example, in Suriname, the colonists, the local governing council and the Suriname Company could not come to an agreement over who was to pay for the building of a strategically placed fortress Nieuw Amsterdam and a line of smaller strongholds along the river mouth. The States General, however, intervened and assured that both the colonists and the company contributed to the building project. ${ }^{75}$

\footnotetext{
71 Heijer, Goud, Ivoor en Slaven, 368-369.

72 Postma, The Dutch, 206.

73 Den Heijer, Goud, Ivoor en Slaven, 370.

74 Stéphanie Kraakman, "De vrije vaart op Elmina. De slavenhandel en de wic na da verandering van het monopolie in 1730," 2013, https://openaccess.leidenuniv.nl/handle/ $1887 / 21570$.

75 Conventie tusschen de directeuren van de geoctroyeerde societeyt van Suriname ter eenre en gemagtigde van raaden van policie der voorschreeve colonie, mitsgaders van veel voornaame en meest gedistingueerde ingeseetenen en geinteresseerdens in deselve colonie, ter andere zyde: By haar Hoog Mog. geapprobeert den 19 December 1733 (The Hague:J. Scheltus, 1734); Julien Wolbers, Geschiedenis van Suriname (Amsterdam: Emmering, 1970), 97-98; Jan Jacob Hartsinck, Beschryving van Guiana, of de Wildekust in Zuid-America, vol. 2 (Amsterdam: Gerrit Tielenburg, 1770), $728-738$.
} 
Hardly were the troubles surrounding the building of the fortress dealt with before the landed conflicts between the colonists and inland maroon communities flared up. This resulted in a period of sustained conflict from the $1750 \mathrm{os}$ until the early $1790{ }^{76}{ }^{76}$ After crushing the 1763 slave revolt in Berbice, the victorious commander Louis Henri Fourgeoud in the service of the States General was relocated to Suriname in 1773 to fight the maroons and to lay out a 100 kilometer long line of defense through the Surinamese jungle. ${ }^{77}$ The costs of the war against the maroons and the manning of the defense barrier and the peopling of a buffer zone were enormous. In the 1750 os the payment of military personnel alone already amounted to about 3.5 million guilders a year. In the seventies this rose to as much as 8 million, not much less than the expenditure on "defense on land" within the Dutch Republic itself. ${ }^{78}$

Thus, far from expanding their trade in a non-territorial fashion, the military conquest and protection of small but important footholds on the African and Caribbean coast were of prime importance to the continued prominent role of the Dutch in the Atlantic, including the trans-Atlantic slave-trade as well as the sale of typical eighteenth century slave-produced boom-products such as sugar and coffee. Cooperation between the States General, the Admiralty Boards and commercial companies remained crucial to the fulfilling of Dutch imperial ambitions. The parceling out of administrative tasks to "brokerage" institutions such as the WIC and the Suriname Society did not reflect a lack of interest in Atlantic territories by the state, but mirrored the federal and brokerage structure of the Dutch state at home. Finally, the fact that formal ownership over these overseas territories was private, does not mean the States General did not care for their "Dutchness." If by nothing else, this is shown by the seamless transition of the Dutch West Indian possessions from brokerage rule to nationalized state-control that followed the collapse of the WIC in 1791 and the abolition of the Society of Suriname by the new Batavian regime in $1795 .{ }^{79}$

76 Wim S.M. Hoogbergen, The Boni Maroon wars in Suriname (Leiden / New York: Brill, 1990).

77 Wolbers, Geschiedenis van Suriname, 325-325.

78 John Gabriel Stedman, Narrative of a Five Years' Expedition against the Revolted Negroes of Surinam, in Guiana, on the Wild Coast of South America, from the Year 1772 to 1777 (London: J. Johnson \& J. Edwards, 1796). During the 1770s, the Province of Holland (responsible for about $58 \%$ of the total state budget) expended around 5.5 million guilders per year on "defense on land." Figures in R. Liesker and W. Fritschy, Gewestelijke financiën ten tijde van de Republiek der Verenigde Nederlanden. Volume IV: Holland, 1572-1795 (The Hague: Instituut voor Nederlandse Geschiedenis, 2004), 394-395.

79 On the transition, see Gerrit Jan Schutte, De Nederlandse patriotten en de koloniën. Een onderzoeknaar hun denkbeelden en optreden, 1770-180o (Utrecht: Rijksuniversiteit Utrecht, 1974). 


\section{Conclusion}

Far from exhibiting an example of "expansion without empire," Dutch success in the Atlantic crucially rested on the combination of commercial activity and military power-projection. Without a territorial base, neither the prominent role of the Dutch in trans-Atlantic slave trade (carrying about 5 percent of all the enslaved from Africa to the Americas), nor the dynamic role of trade in Atlantic goods in the eighteenth century Dutch economy would have been feasible.

While territoriality did not take the shape of a clearly focused, politically centralized empire, the long-lasting Dutch presence in the Atlantic world was no less underpinned by military might than that of its competitors. Neither did the substantial outsourcing of state-like responsibilities to commercial companies formally independent of the state signify a real absence of imperial ambitions or state intervention. The power of the VOC and wIC never exceeded the limits of what was granted by the States General's charter, and at crucial points in their existence it was only the direct armed intervention by state troops and ships that secured Dutch trans-oceanic commerce. Short lines of communication between the directors of commercial companies and state institutions, most crucially in the case of commercial protection the Admiralty Boards, made sure East- and West-India interests were well reflected in the long-term strategies pursued by the States General. Important changes in the territorial shape of the Dutch Atlantic were always concomitant to European great power struggles, and had to be sanctioned by inter-state treaties. Finally, the suggestion that after the collapse of Dutch Brazil in 1654 and the definitive loss of the New Netherland colonies in 1674 Dutch territories were too small to be considered a "real empire," lacks substance. Of course, the eighteenth-century Dutch possessions never met the standards Dutch expansionists had originally set for themselves in their Grand Design. Nevertheless, without a significant territorial base overseas guaranteed by military might the Dutch would have lost out not only as empire-builders, but as commercial middlemen as well. Knowing this, Dutch investors and politicians were willing to muster military force to prop up their territorial rule in the Atlantic even beyond the eighteenth century. 


\section{Appendix 1}

TABLE 4.2 West Indian careers of Amsterdam Admiralty Board administrators

\begin{tabular}{|c|c|c|}
\hline Name & $\begin{array}{l}\text { Position on Amsterdam } \\
\text { Admiralty Board (years) }\end{array}$ & $\begin{array}{l}\text { West Indian connection } \\
\text { (years start and end of } \\
\text { term when available) }\end{array}$ \\
\hline Gijsbert van Hemert & Delegate $\left(1645^{-1648}\right)$ & Director WIC (?) \\
\hline Albert Bas & Delegate $(1648-1650)$ & $\begin{array}{l}\text { Director WIC (1645), } \\
\text { Hoofdparticipant WIC (?) }\end{array}$ \\
\hline Cornelis Witsen & Delegate $(1654-1658)$ & $\begin{array}{l}\text { Director WIC (1645), } \\
\text { Hoofdparticipant WIC (1658) }\end{array}$ \\
\hline Johan van der Merct & Delegate $(1657-1661)$ & $\begin{array}{l}\text { Director WIC (?), } \\
\text { Hoofdparticipant WIC (?) }\end{array}$ \\
\hline Cornelis de Lange & Delegate $(1668-1671)$ & Director WIC (1677-1682) \\
\hline Wigbolt Slicher & $\begin{array}{l}\text { Receiver-General } \\
(1669-1713)\end{array}$ & Hoofdparticipant $\left({ }_{1658)}\right.$ \\
\hline Hendrik Brouwer & Delegate $(1674-1676)$ & Hoofdparticipant (1658) \\
\hline Adriaen Backer & Delegate $(1679-1684)$ & $\begin{array}{l}\text { Director Society of Suriname } \\
\text { (169o) }\end{array}$ \\
\hline Mattheus Schatter & Delegate $\left(1685^{-1689}\right)$ & Director WIC (?) \\
\hline Nicolaes Opmeer & Delegate (1688-1691) & Director WIC (1682) \\
\hline Tinco van Andringa & Delegate (1689) & Director WIC (1689) \\
\hline Joan de Vries & Delegate $(1691-1708)$ & $\begin{array}{l}\text { Director Society of Suriname } \\
(1689)\end{array}$ \\
\hline Boudewijn Jongkint & $\begin{array}{l}\text { Delegate }(1702-1706, \\
1709-1712)\end{array}$ & Director WIC (1695-1713) \\
\hline Nicolaas Sautijn & $\begin{array}{l}\text { Fiscal Advocate } \\
(1707-1718), \text { Delegate } \\
\left(1733^{-1743)}\right)\end{array}$ & $\begin{array}{l}\text { Presiding Director wIC } \\
(1721), \text { Director Society of } \\
\text { Suriname }(1721)\end{array}$ \\
\hline Cornelis Munter & Delegate $(1708)$ & $\begin{array}{l}\text { Director WIC (1698), Director } \\
\text { Society of Suriname }(1698)\end{array}$ \\
\hline $\begin{array}{l}\text { Jeronimus de Haze de } \\
\text { Gregorio }\end{array}$ & Delegate $(1710-1711)$ & Director WIC (1696) \\
\hline Reinier Crabeth & Delegate (1732-1749) & Director WIC (1746-1748) \\
\hline Pieter van den Broek & Delegate $\left(1748-175^{8}\right)$ & Director WIC (1751) \\
\hline Egbert de Vrij Temminck & Delegate (1748-1749) & Director WIC (1738) \\
\hline
\end{tabular}


TAB LE 4.2 West Indian careers of Amsterdam Admiralty Board administrators (cont.)

\begin{tabular}{|c|c|c|}
\hline Name & $\begin{array}{l}\text { Position on Amsterdam } \\
\text { Admiralty Board (years) }\end{array}$ & $\begin{array}{l}\text { West Indian connection } \\
\text { (years start and end of } \\
\text { term when available) }\end{array}$ \\
\hline Gerrit Hooft & Delegate $\left(175^{6-1} 7^{6} 3\right)$ & $\begin{array}{l}\text { Director WIC }(1709-1716) \text {, } \\
\text { Director Society of Suriname } \\
(1710-1716)\end{array}$ \\
\hline Cornelis Hop & $\begin{array}{l}\text { Delegate }\left(175^{8-1759},\right. \\
1761-1762)\end{array}$ & $\begin{array}{l}\text { Director WIC (1716-1753), } \\
\text { Director Society of Suriname } \\
\left(1734-175^{\circ}\right)\end{array}$ \\
\hline Francois de Mey & $\begin{array}{l}\text { Delegate }(1761-1764, \\
1773^{-1776)}\end{array}$ & Director WIC $(1784)$ \\
\hline Nicolaes van Alphen & Delegate $\left(1763^{-1764)}\right.$ & Director WIC (1771-1784) \\
\hline $\begin{array}{l}\text { Hendrik Baron van } \\
\text { Isselmuden tot Paaslo }\end{array}$ & Delegate $\left(1763^{-1765)}\right.$ & Director WIC (1759) \\
\hline Gerrit Gerritsz Hooft & Delegate $(1767-1770)$ & $\begin{array}{l}\text { Director Society of Suriname } \\
\left(175^{1}\right)\end{array}$ \\
\hline $\begin{array}{l}\text { Borchard Herman } \\
\text { Gansneb }\end{array}$ & Delegate $(1770-1771)$ & Director WIC (1772) \\
\hline Daniel Deutz & Delegate $\left(177^{0}-1775\right)$ & $\begin{array}{l}\text { Director Colony of Berbice } \\
(1757)\end{array}$ \\
\hline $\begin{array}{l}\text { Johan Cornelis van der } \\
\text { Hoop }\end{array}$ & $\begin{array}{l}\text { Fiscal Advocate } \\
(1781-1795)\end{array}$ & $\begin{array}{l}\text { Secretary of Society of } \\
\text { Suriname (1769), Director of } \\
\text { Society of Suriname (1782) }\end{array}$ \\
\hline Pieter Clifford & Delegate $\left(1783^{-1784}\right)$ & Director WIC $(1761)$ \\
\hline Joachim Rendorp & Delegate $(1787-1789)$ & $\begin{array}{l}\text { Director Society of Suriname } \\
\left(175^{8}\right)\end{array}$ \\
\hline $\begin{array}{l}\text { Jan Elias Huydecoper } \\
\text { van Maarseveen }\end{array}$ & $\begin{array}{l}\text { Delegate }(1789-1791, \\
1793^{-1794)}\end{array}$ & $\begin{array}{l}\text { Director Colony of Suriname } \\
(1793)\end{array}$ \\
\hline
\end{tabular}

SOURCES: SEE BRANDON, MASTERS OF WAR, ANNEX 1. 